\title{
THE EYELESS CATOPOCERUS BEETLES (LEIODIDAE) OF EASTERN NORTH AMRICA*
}

\author{
By Stewart B. Peck \\ Department of Biology, Carleton University \\ Ottawa, Ontario, Canada KIS 5B6
}

The Leiodid beetle genus Catopocerus Motschoulsky ${ }_{1} 869$ is composed exclusively of small ( I.8-4.5 mm body length), eyeless, wingless, partially depigmented inhabitants of moist forest soil and duff, and occasionally of caves. The genus, the only member of the subfamily Catopocerinae, is known to occur only in North America. The distribution of the genus is principally the unglaciated mountain forests of the eastern and western portions of the continent.

Hatch (1957) has reviewed the nine described species from western North America. These range from the San Francisco area northward in coastal forests to Sitka, Alaska. Undescribed species occur in this region and also in southern California, Arizona, and Colorado (personal data). The known and new western species will be covered in a future paper which will also include data from an assemblage of over 2000 specimens collected throughout Oregon by Ellen Benedict of Portland State University.

This paper reports on the two described eastern North American species, and describes three new eastern species.

The genus possesses a character common to the family; the eighth antennal segment is smaller than either the seventh or ninth segments (except in C. pusio Horn of California in which the seventh and eighth segments are equally small). They may be distinguished from other leiodids by a combination of the following characters: eyelessness, winglessness, oval shape, dorsal-ventral flattening, open procoxal cavities, five segmented abdomen, and separated metacoxae (Peck, 1973:50).

\section{Methods}

In the field, series of specimens were taken from moist forest litter, soil, and well-rotted logs. The debris was sifted in the field through a one-half inch mesh screen to remove large objects. The sifted debris was carried and stored in large plastic bags until it could be processed in "Berlese" funnels. When processed, three liters of litter were placed in each funnel $(45 \mathrm{~cm}$ high, $30 \mathrm{~cm}$ across the top, with the

*Manuscript received by the editor December 17, 1974. 
screen Io $\mathrm{cm}$ from the top) on a double layer of cheesecloth supported by the screen. A 40 watt bulb was used over the litter. Two thin wood strips held the top of the funnel above the rim of the bottom and provided ventilation and for the escape of excess moisture. Beetles stopped falling into the collecting bottle at the bottom of the funnel in less than I 2 hours. During periods of maximum operation, up to 24 funnels were used, each holding three liter samples of sifted litter for twelve hours. Thus, up to 144 liters of sifted litter could be processed each day.

From 1967 to 1974 , in search of Catopocerus and other leiodid beetles, I have extracted the fauna in the above method from $436 \mathrm{I} \mathrm{kg}$ of sifted forest litter from the eastern United States. Most of the beetles extracted have been deposited with the CNCI and FMNH, and the arthropod residues are in the FMNH.

Barber's Fluid (Valentine, I942) was used as a preservative under the funnels. Species determination can be reliably made only by examination of the male genitalia. This examination is facilitated by the Barber's Fluid which does not harden the tissues of the beetles as does alcohol. The few specimens found under rocks were collected into Barber's Fluid. Some specimens were collected in caves at rotted pig liver bait, and in carrion baited pitfall traps (Peck, I973). Specimens were cleaned of adhering debris by an ultrasonic cleaner. Dry material was relaxed in boiling water. Dissections were made with minuten needles, in alcohol. Genitalia were observed in alcohol, as temporary glycerine mounts, and dry. Specimens were mounted on points using an alcohol soluble glue. Illustrations were prepared from temporary glycerine mounts.

Measurements are given in millimeters, and were made using a calibrated ocular micrometer disc. The following abbreviations are used in the paper: HW, head width; PW, pronotal width; PL, pronotal length; EL, elytral length; and EW, elytral width. Lengths were measured along the midline. Elytral lengths are from the apex of the scutellum. Widths are maximum widths. Rounded surfaces are measured as chords of arcs.

The following abbreviations are used to indicate the sources of the material examined: AMNH, American Museum of Natural History; ANSP, Academy Natural Sciences Philadelphia (Horn colln., now in MCZ); CAS, California Academy of Sciences; CM, Carnegie Museum; CNCI, Canadian National Collection of Insects; FMNH, Field Museum of Natural History; INHS, Illinois Natural History Survey; MCZ, Museum Comparative Zoology, Harvard University; SBP, Stewart B. Peck; SVAM, St. Vincent Archabbey Museum 
Collection, Latrobe, Penn.; UK, University of Kansas, Entomology Collection; USNM, United States National Museum.

\section{Bionomics}

The general collector may occasionally encounter Catopocerus under large rocks and logs in mountain forests. Large series are most usually taken in the spring and fall and only by extraction from soil and litter with the Tullgren modification of a Berlese funnel. Some species have been found in caves in the eastern interior low plateaus. Here they are usually under rocks in organic soil near cave entrances. The use of carrion bait has been useful in attracting the beetles in caves.

Food probably consists of organic debris and associated yeasts and fungi. Several species of Catopocerus have been repeatedly taken on subterranean fungi in Oregon and Washington (Fogel and Peck, in MS) and the eastern species may have similar habits. A laboratory colony of the beetles reproduced and developed on bakers yeast on moist soil. C. hamiltoni was taken congregated around a dead beetle larva, and the many beetles taken on carrion bait in caves were undoubtedly attracted to the carrion for the purposes of feeding and/or oviposition.

Only one certain case of sympathy is known. Thirty-four $C$. ulkei and i $C$. appalachianus were taken together in Io $\mathrm{kg}$ of litter near Whitmer, W. Va.

Reproduction may occur throughout the year in caves, but in forest litter is probably most active in the spring. Larvae and teneral adults have been found most commonly in early spring in litter. One species has been reared from eggs. At $15^{\circ} \mathrm{C}$, the egg stage lasts about $\mathrm{I} 7$ days, the larval stage about 29 days, and the pupal stage 20 days.

Three species have been found in caves in Alabama and Tennessee. However, this association with caves is only facultative, for these soilinhabiting (edaphobitic) beetles probably accidentally enter caves, but once there can survive and reproduce.

One of these species, $C$. appalachianus is found at higher elevations in the Appalachians near the soil surface under rocks and in litter. If the preferred environment of the beetles is a montane type of stable, cool, and moist environment, this will be found at lower elevations deeper in the soil. Collecting of surface soil and litter has never taken the beetles at the lower elevations of the Cumberland Plateau or Highland Rim of Alabama or Tennessee. Thus, in the cave region, the beetles' normal soil habitat must be too deep to be 

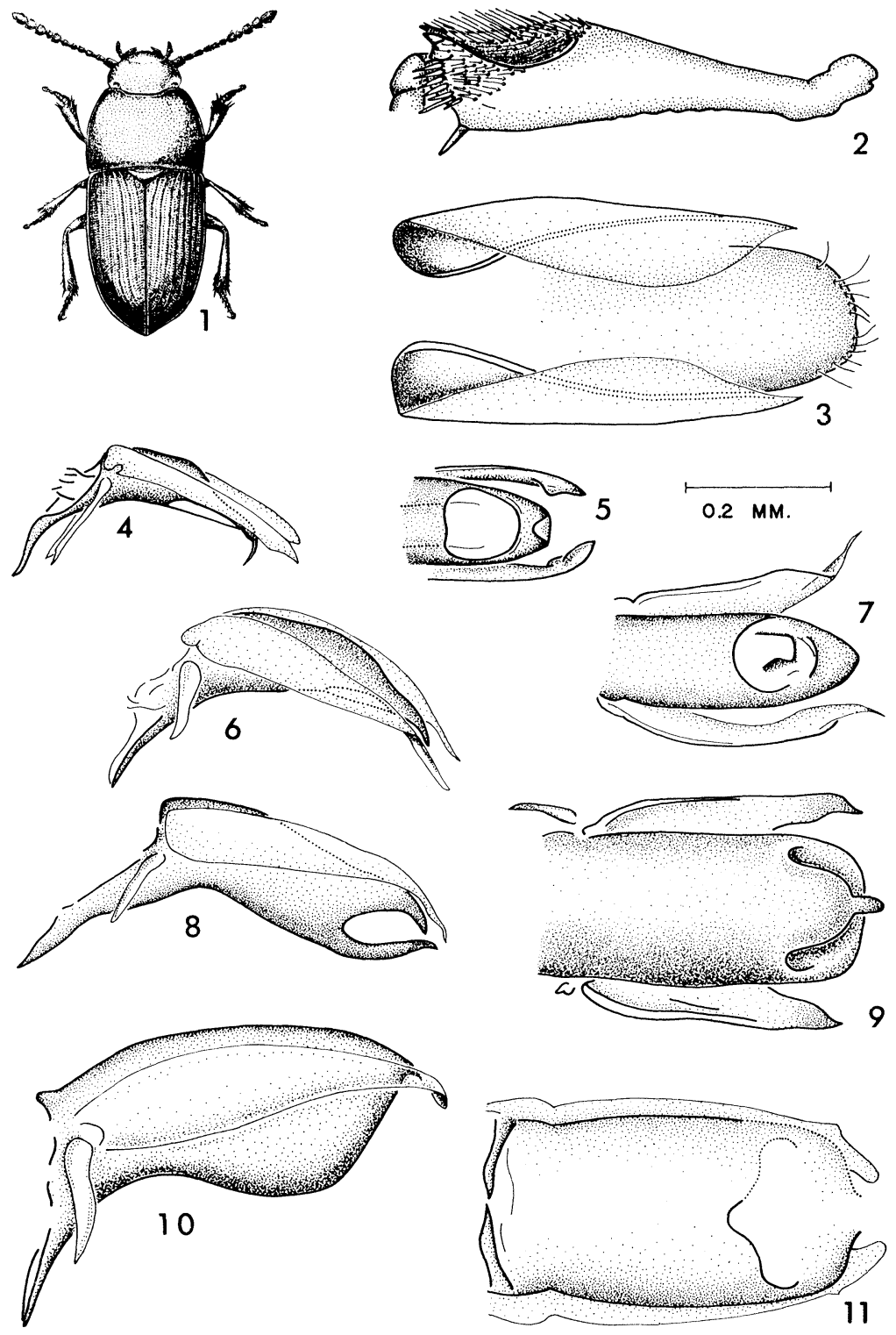
normally sampled, and this deep soil habitat will bring the beetles into frequent contact with rock crevices filled and partly filled with soil, which may open into caves with their cool and moist conditions. Hence, in the southern Appalachians, caves can be a more convenient sampling site for soil inhabitants which are usually hidden under a concealing thickness of soil. Other such montane soil inhabitants that are infrequently found at lower elevations except in caves are Anillinus carabids (Barr, 1969) and Arianops pselaphids (Barr, 1974). Collecting in prolonged wet weather or during winter months might find all of these beetles closer to the surface in the Cumberland Plateau or Highland Rim regions of Alabama and Tennessee.

\section{Artificial key to the Catopocerus}

ra. Body length $4 \mathrm{~mm}$ or over C. hamiltoni

Ib. Body length $3 \mathrm{~mm}$ or under 2

2a. Hind tibia with setal bearing excavation on dorsal posterior surface (fig. 2)

C. alabamae, n. sp.

2b. Hind tibia with setae only, no excavation on dorsal posterior surface

3a. Third antennal segment clearly longer than second, five clearly larger than four and six; northeastern Alabama $C$. jonesi, n. sp.

3b. Third antennal segment as long as or only slightly longer than the second, five the same size as four and six; widely distributed

4a. Tip of aedeagus curved downward, forming $80^{\circ}$ to $100^{\circ}$ angle with ventral surface of aedeagus (Fig. 4)

C. ulkei

4b. Tip of aedeagus only slightly curved downward, angle with ventral surface of aedeagus $135^{\circ}$ or greater (Fig. 6)

C. appalachianus, n. sp.

\section{Catopocerus hamiltoni (Horn)}

Fig. 3; Map 2

Pinodytes hamiltoni Horn, 1892:45. Lectotype here designated as female in MCZ, Horn colln. (no. 3027), seen. Type locality: "vicinity of Allegheny City", Pennsylvania.

Figures 1-11. 1, habitus of Catopocerus appalachianus. 2, metatibia of C. alabamae. 3, aedeagus of C. hamiltoni. 4, side of aedeagus of $C$. ulkei. 5, ventral tip of aedeagus of $C$. ulkei. 6, side of aedeagus of $C$. appalachianus. 7, ventral tip of aedeagus of $C$. appalachianus. 8, side of aedeagus of $C$. jonesi. 9, ventral view of aedeagus of $C$. jonesi. 10, side of aedeagus of C. alabamae. 11, ventral view of aedeagus of $C$. alabamae, tip incomplete because of damage in dissection. Scale line for figs. 3-11 only. 
Diagnosis. The large size, the third antennal segment which is I.5 times or more the length of the second segment, and the shape of the aedeagus serve to distinguish this species.

Redescription. Measurement of lectotype: HW, 0.85. PW, 1.63. PL, r.23. EW, r.63. EL, 2.74.

Length 4.I-4.7 mm. Width r.66-I.73 mm. Color uniform dark reddish-brown, shining. Shape oblong, moderately elongate, not very convex.

Head without trace of eyes; sparsely punctate. Antennae well supplied with long hairs throughout length, last three segments with dense vestiture; segment III I.5 $X$ or more the length of II; III slightly wider than II; IV, V, VI as wide as II, subglobose, slightly longer than wide; VII, IX, X cup shaped; VII longer than but narrower than IX and $X$; VIII shorter than but slightly wider than $\mathrm{VI}$; XI conical.

Pronotum widest at middle, sides evenly arcuate; narrower at front than back; hind angles rectangular; front angles rounded; front margin evenly emarginate to receive head; hind margin weakly convex; disc finely but not closely punctate; covered with fine strigae.

Elytra fused; at base slightly wider than base of pronotum; widest at middle; sides slightly arcuate; narrowing in apical third; each with seven striae of close punctures, less distinct at sides and apex, intervals flat, sparsely punctate.

Protibia gradually widening to apex; setose on apical half of inner margin. Mesotibia gradually widening to apex; sharply outward flaring in outer margin at apex; spinose on outer concave margin; inner margin sinuous; setose on apical half of inner margin. Metatibia gradually widening to apex; inner and outer margin slightly sinuous; setae on apical half of inner margin. Penultimate abdominal segment, fourth, with transverse depression on either side.

Male protarsomeres not dilated. Abdominal segment five truncate. Aedeagus poorly sclerotized; thin and straight in lateral view; wide and straight in dorsal view; tip dorsoventrally flattened, slightly upturned at edge, smoothly rounded in dorsal view, I 4 setae along edge; parameres separated, longest on ventral surface but not reaching tip of aedeagus, partially covering anterior ventral surface and dorsal median surface of aedeagus (fig. 3).

Female abdominal segment five rounded.

Note on lectotype. The specimen is damaged. It possesses only two prothoracic and one metathoracic legs. One antenna is missing its terminal segments. 
Distribution. Southwestern Pennsylvania (map 2). The type locality, Allegheny City, lying on the north shore of the confluence of the Allegheny and Monongahela Rivers, was incorporated into the city of Pittsburgh near the beginning of this century.

Material examined. Pennsylvania. Allegheny, I female, lectotype 3027 (ANSP) ; 2, (ANSP, CM). Beatty, I female (USNM). Charleroi, 2 (MCZ, UK). Jeannette, vi. I90I, 2 (CM). Pittsburgh, ix, 2 (CM). St. Vincent, 3 (Ulke colln. in CM; MCZ). Washington Co., I female (Fall colln. in MCZ). State label only, I paratype no. 3027 (ANSP); i (UK).

Biology. The available information on the species has been presented by Hamilton ( 1897 ). He found the first specimen in December, I872, "about a foot under ground beneath a large impacted boulder in a wild mountainous place." Several individuals were seen but only one was collected because the pale color and remarkable swiftness led Hamilton to believe they were young roaches. This and a second specimen found dead by Hamilton the following June on a wooded hillside were those which Horn had for description. Other specimens were taken later by other collectors in winter months under bark, under stones, and by sifting decaying leaves. A group of twelve was taken in late November under a $\log$ in a wooded ravine around a large dead elaterid beetle larva upon which they were probably feeding. I have not seen specimens taken since the turn of the century.

\section{Catopocerus ulkei Brown}

Fig. 4, 5 ; Map I

Catopocerus ulkci Brown 1933; 215. Holotype female in CNC, seen. Type locality; District of Columbia.

Pinodytes cryptophagoides Mannerheim (in part), Horn, 1880: 249; 1892: 46; Hamilton, 1894: 16. Misidentified.

Diagnosis. The species is separated from others by its small size, the subequal second and third antennal segments, and the flattened, downward curved tip of the aedeagus.

Redescription. Length I.4-2.2 mm. Width 0.7 I-0.94 mm. Color uniform dark reddish-brown, shining. Shape oblong.

Head with trace of eyes as depigmented spot on side of head in some pale specimens; vertex finely punctulate, finely striolate. Antennae well supplied with hairs throughout length; segments VII, IX, $\mathrm{X}$ supplied with dense vestiture of long and short hairs; I stout; II and III equally long; III narrower at base than II ; IV, V, VI equal, globose; VII as long as broad; VIII smaller than VII, larger than 


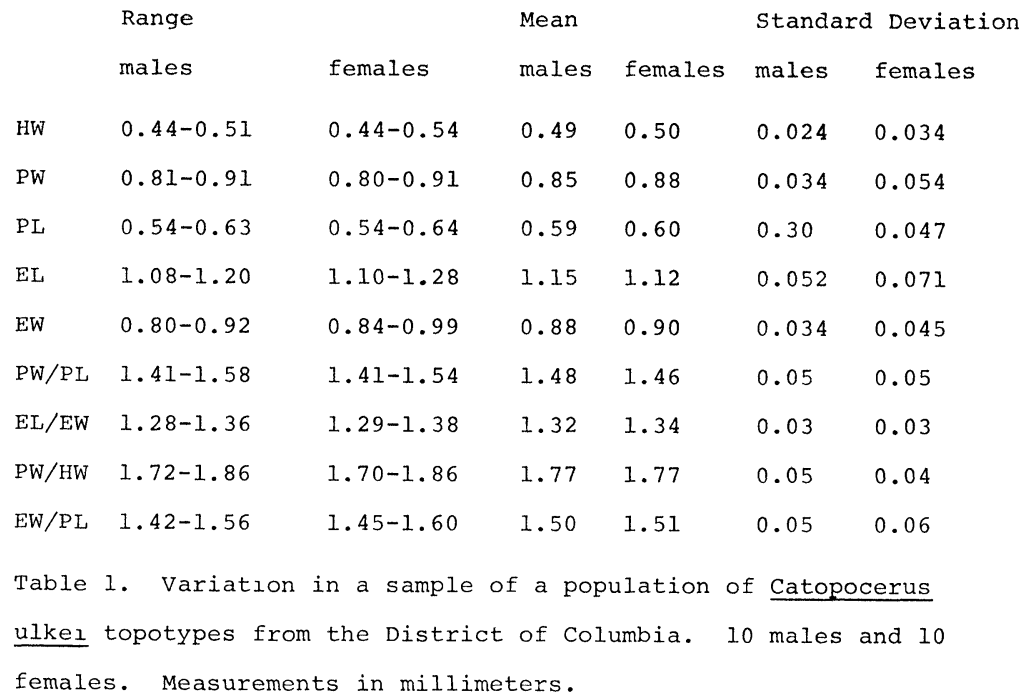

VI; IX smaller than $\mathrm{X}$, larger than VII; IX and $\mathrm{X}$ broader than long; XI conical.

Pronotum widest just behind middle; sides evenly arcuate; narrower at front than back; hind angles slightly obtuse; front angles rounded; front margin slightly concave; hind margin straight; disc finely and sparsely punctulate; finely striolate.

Elytra fused; at base slightly wider than base of pronotum; widest at middle; sides slightly curved; narrowing in apical third; surface finely punctate, some punctures vaguely indicating striae; finely striolate; apical declivity smooth.

Protibia widening to apex in distal $2 / 3$; setose on apical half of inner margin; mesotibia gradually widening to apex in apical 2/3; inner margin setose in apical third, faintly sinuous; outer margin spinose; outer apical angle truncate. Metatibia gradually widening to apex; outer margin smooth; inner margin smooth to serate; outer apical angle slightly truncate.

Male first four protarsomeres dilated and supplied with long lateral hairs; first three mesotarsomeres feebly dilated. Aedeagus in lateral view arcuate; ventral surface of anterior end projecting forward and curved downward; tip dorsoventrally flattened and turned downward forming $80^{\circ}-100^{\circ}$ angle with ventral surface of aedeagus; parameres long and thin, exceeding tip of aedeagus, hinged at aedeagus base to ventrally deflected elongate basal pieces (figs. 4, 5). 
Female tarsomeres not expanded; abdominal segments as in male.

Variation. Table I presents meristic variation for the topotypic population. All populations examined which are assigned to this species have aedeagi of the males identical to aedeagi of the topotypic population but for two exceptions. The two samples from southwestern North Carolina are 220 air miles to the southwest of the next nearest locality from which males have been collected. These southwestern collections differ in the angle of deflection of the aedeagal tip. A distinct acute angle of about $80^{\circ}$ is formed between the ventral surface of the aedeagus and the tip of the aedeagus. All other populations possess aedeagi in which the angle is usually slightly obtuse. Only rarely is it a right angle.

The variation of measurements for a sample of four males and eight females from Joanna Bald, Cherokee County, North Carolina, when compared to that in table I, showed that the size of the southern populations is larger, but there is a great deal of overlap within the range of the measurements. Variation of the ratios, when compared to the topotypic population shows less difference, and that which does exist is contained within an overlap of one standard deviation from each mean. This numerical data demonstrates little or no difference from the topotypic $C$. ulkei. Since there is a large gap in knowledge of the range of the species between western Virginia and southwestern North Carolina, I am unwilling to interpret the taxonomic significance of the greater curvature of the tip of the aedeagus in the southwestern North Carolina populations. It may be a distinct subspecies if its distribution is geographically separated from typical C. ulkei. Or the population may represent one end or segment of a cline of gradual deflection of the aedeagal tip. Further collecting may tell.

Distibution. The species is known to occur in southwestern and southeastern Pennsylvania, the District of Columbia, Maryland, North Carolina, Virginia, and West Virginia (map I). Future collecting might show it to be continuously distributed along the Piedmont and eastern edge of the Appalachians to the southern known locality in Cherokee County, North Carolina.

Material examined and habitat data. District of Columbia: no other data, 32. Washington, D. C., I ; I.5, I ; 5.3, I ; Hubbard \& Schwarz. Maryland: Garrett Co.; Deer Park, 4.7, I, Hubbard \& Schwarz; 2 mi. E. Keysers Ridge, 2500' elev., I8.vi.r 968, S. Peck, 3 in 220 lbs. log-stump litter. North Carolina: Cherokee-Graham County; Andrews, Joanna Bald, 4700' elev., 26.vii.I967, S. Peck \& A. Fiske, 13 in 89 lbs rotted chestnut log; Joanna Bald, 5.viii.r96o, 


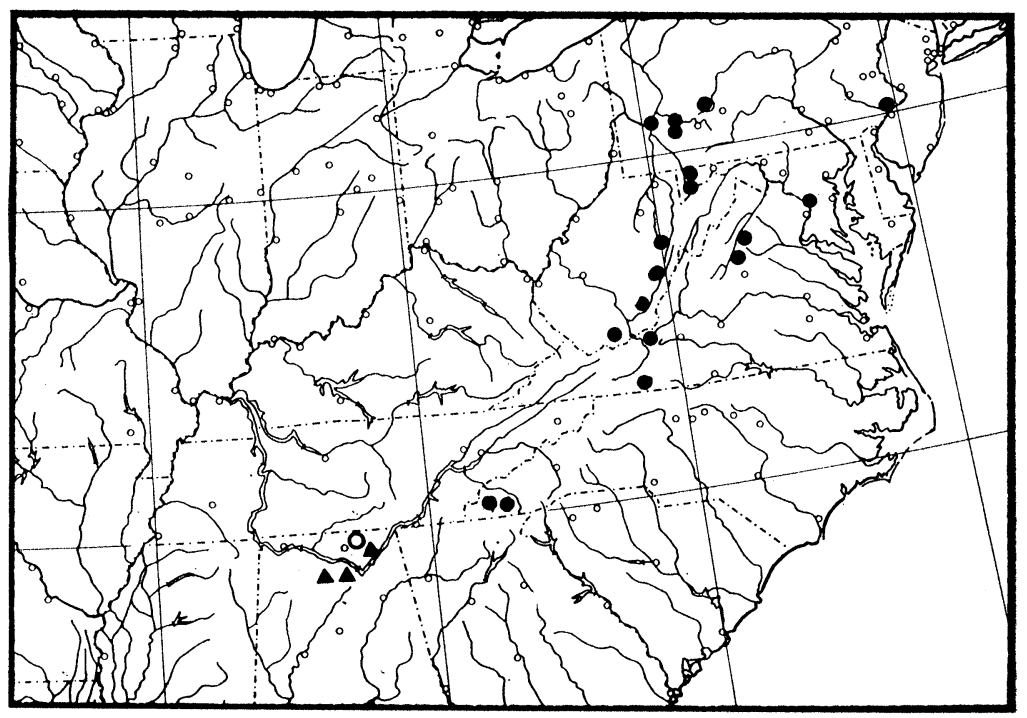

Map 1. East central United States and Catopocerus distributions. Closed dots, $C$. ulkei. Open dot, C. alabamae. Closed triangles, $C$. jonesi.

T. C. Barr, I male. Clay-Macon County; Tusquitee Bald, 4.viii. I960, T. C. Barr \& M. C. Bowling, I male. Pennsylvania: x, I. Allegheny County; Pittsburgh, x, 3. St. Vincent, 9. Cambria County; Nicktown, M. Wirtner, 3. Philadelphia County; 28.vi. I9I I, G. M. Greene, I. Westmoreland County; Chestnut Ridge, E. of Youngstown, 27.vi.196I, W. Suter, I in litter under Rhododendron; I I.vii.I96I, W. Suter, J. Wagner, D. Reichle, I in forest litter. Jeannette, vii, 2; ix, 3; x, I. Virginia. Caroll County; Groundhog Mt., 2900' elev., Blueridge Parkway, 23.vii.1967, S. Peck \& A. Fiske, I female in $46 \mathrm{lbs}$. rotted stump and log litter in Rhododendron thicket. Giles County; Mountain Lake, I-5.vii. 1970, W. B. Muchmore, 8. Madison County; Shenandoah National Park. Dark Hollow Falls, 2.iv.1967, S. Peck, I under rocks. Lewis Mt., 2000' elev., Io.vi.1967, S. Peck, IO4 in rotted logs. Page County; Shenandoah National Park. Hawksbill Mt., I 7.x.1954, D. G. Kissinger, I. Stony Man Overlook, 2.iv.1967, S. Peck, 3 under rocks and 6 in litter. West Virginia. Greenbrier County; outside Arbuckle Cave, I4.vii.ı70, W. B. Muchmore, I in litter. Mercer County; 5.5 mi. N. Princeton, Brush Creek Falls, I3.v.197I, W. Shear, I in cliffside litter. Pocahontas County; W. side Cranberry Glades, base of mountain, streamside, under rock, 28.vi.1967, T. C. 
Barr, I female. Hills Creek Falls, 6.v.1970, W. Shear, I; I9.vi. 1971, Shear and Platnick, 2. Randolf County; Bickle Knob, 380o' elev., E. of Elkins, I9.vi.r 968, S. Peck, 34 in I 79 lbs. of log litter. 5 mi. S. Whitmer, I 8.vii.197I, S. Peck, 3000' elev., 34 in litter. (AMNH, CAS, CM, CNC, FMNH, INHS, SBP, SVAM, UK, USNM).

\section{Catopocerus appalachianus New Species Fig. 6, 7 ; Map 2}

Holotype male ( $\mathrm{MCZ}$ no. 32228) from Balsam Gap, 5500' elev., Mt. Mitchell, Yancey Co., North Carolina, 9.vi.1967, S. Peck. Paratypes: all material listed in section on material examined.

Diagnosis. Most similar to $C$. ulkei but differing distinctly from it and all other species in the shape of the aedeagus. Usually differing from C. ulkei in its larger size and greater EW/PL ratio.

Description. Length 2.I 4-2.86 mm. Width o.83-I.IO mm. Color uniform dark reddish-brown, shining. Shape oblong.

Head with faint trace of eyes as depigmented spots on side of head in pale specimens; vertex finely punctulate, finely striolate. Antennae with long hairs throughout length; segments VII, IX, X with dense vestiture of long and short hairs; segment I stout; II stouter and only slightly shorter than III; IV, V, VI subglobose and subequal; VII as long as broad, widest at apical third; VIII as long as and wider than VI, smaller than VII and IX; IX and X of equal length, $\mathrm{X}$ wider; $\mathrm{XI}$ conical.

Pronotum widest at basal third; sides evenly arcuate; narrower at front than back; hind angles slightly obtuse; front angles rounded; front margin slightly concave; hind margin straight; disc finely and sparsely punctulate; finely striolate.

Elytra fused; at base slightly wider than base of pronotum; widest near middle, sides slightly curved; narrowing in apical third; surface finely punctate, punctures indicating striae; finely striolate; apical declivity smooth.

Protibia widening to apex in distal 2/3; setose on apical half of inner margin; a few spines on apical half of outer margin. Mesotibia straight along outer margin; expanding gradually along inner margin to apex from proximal third; inner margin setose in apical third, faintly sinuous; outer margin spinose; outer apical angle rounded. Metatibia gradually widening to apex; outer margin smooth; outer apical angle slightly truncate, possessing two large spines; dorsal surface of apical end with patch of setae; slight downward bow in middle in lateral view. 


\begin{tabular}{|c|c|c|c|c|c|c|}
\hline & Range & & Mean & & Standard & Deviatzon \\
\hline & males & females & males & females & males & females \\
\hline $\mathrm{HW}$ & $0.49-0.70$ & $0.48-0.63$ & 0.60 & 0.55 & 0.070 & 0.054 \\
\hline PW & $0.81-1.15$ & $0.84-1.08$ & 1.01 & 0.95 & 0.097 & 0.080 \\
\hline $\mathrm{PL}$ & $0.58-0.80$ & $0.55-0.75$ & 0.70 & 0.68 & 0.072 & 0.064 \\
\hline EL & $1.15-1.55$ & $1.19-1.54$ & 1.40 & 1.34 & 0.131 & 0.107 \\
\hline $\mathrm{EW}$ & $0.84-1.14$ & $0.89-1.10$ & 1.00 & 0.98 & 0.094 & 0.074 \\
\hline $\mathrm{PW} / \mathrm{PL}$ & $1.36-1.55$ & $1.43-1.60$ & 1.44 & 1.49 & 0.05 & 0.04 \\
\hline $\mathrm{EL} / \mathrm{EW}$ & $1.34-1.44$ & $1.32-1.42$ & 1.36 & 1.38 & 0.04 & 0.04 \\
\hline $\mathrm{PW} / \mathrm{HW}$ & $1.58-1.82$ & $1.69-1.80$ & 1.66 & 1.74 & 0.06 & 0.04 \\
\hline $\mathrm{EW} / \mathrm{PL}$ & $1.90-2.09$ & $1.98-2.24$ & 1.99 & 2.10 & 0.06 & 0.07 \\
\hline
\end{tabular}

Male first four protarsomeres expanded and with long hairs; first three mesotarsomeres feebly dilated; metatibia with inner edge weakly to strongly serrated. Aedeagus in lateral view robust and arcuate; ventral surface of anterior end projecting forward; from base narrowing slightly for $2 / 3$ length, narrowing markedly in distal third, tip slightly downcurved; in ventral view sides expanding slightly for $2 / 3$ length, then evenly converging to tip; tip flattened; parameres gradually tapering to thin point which extends beyond aedeagus tip; basal piece of parameres pointing forwards along sides of aedeagus (figs. 6, 7).

Female tarsomeres not expanded; abdominal segments as in male; inner margin of metatibia smooth.

Variation. Table 2 presents meristic data on the topotypic population. In some specimens the outer margin of the elytra at the anterior angles bears a few coarse, low teeth. The males of the species variably possess a saw-toothed inner margin of the hind tibia, ranging from absent to highly developed.

The variation in size and proportions within this species overlap in some measured populations with $C$. ulkei size and proportions. Hence, care should be used in separating the species using external criteria. A sample of four males of C. appalachianus from Whitetop Mt., Virginia is composed of noticeably smaller individuals. Their 
PL mean corresponds to that of the topotypic population of $C$. ulkei. The Whitetop Mt. sample EW/PL mean also corresponds to that of topotypic $C$. ulkei and not the topotypic $C$. appalachianus sample. This size overlap demonstrates the clear value of using the distinct and less variable features of the aedeagus. Because of these size similarities some female specimens may be difficult to indentify. Locality records for these two species in their zone of overlap may be treated with certainty only when males are present.

Etymology. The name refers to the Appalachian region in which the beetle is found.

Distribution. The species has roughly a linear range of 480 miles along the Appalachian Mts. from Madison County, Alabama northeastward to Pocahontas County, West Virginia (Map 2). It is known from a few intermediate areas in Virginia, Tennessee, and especially from North Carolina in the vicinity of Mt. Mitchell. One collection has been made in the Cumberland Plateau of Kentucky and one in the Shawnee Hills of Southern Illinois.

Material examined and habitat data. Alabama. Madison County: Barclay Cave, 26.vii.ı665, S. \& J. Peck, I in trap; 18.viii.ı965, S. \& J. Peck, I in trap; 20.viii.1965, S. \& J. Peck, I in trap; I.ix.1965, S. \& J. Peck, 2 in trap; 2.vii.1967, S. Peck and A. Fiske, I at carrion bait; 24.viii.I97I, S. Peck, I at bait; I0.v.72, S. Peck, 4 at bait; I3.vii.r973, S. Peck, I at bait. New Hope, Cave Spring Cave, 23. viii. I 97I, S. Peck, 3 at bait in side chamber $400^{\prime}$ in cave. Ellis Cave, 5.vii.r 967 , S. Peck and A. Fiske, 2 at carrion bait; ix.1968, S. Peck, 8 at carrion bait; 2 reared from eggs laid in culture 3.viii.ı 969, S. Peck. Illinois. Union County; Pine Hills Field Station, I 5.v. i 967, J. M. Campbell, I at malt trap site \#9. Kentucky. Harlan County; Big Black Mt., 400o' elev., Ir.vii.r1968, S. Peck, I in 302 lbs. $\log$ and stump litter. Jackson County; The Rises, S. Fork Station Camp Creek, r6.ii. 1967, T. Marsh, W. Andrews, I in log berlese. North Carolina. Avery County: Beech Mt., I 5.vii.r1960, Barr and Bowling, ro; Grandfather Mt., 22.viii.r96o, Barr and Bowling, I male. Blowing Rock to Linville, 3000-4000', 7.ix.I930, P. Darlington, I. Buncombe County: Asheville, A. P. Jacobs, I. Blue Ridge Parkway, $5 \mathrm{mi}$. W. Craggy Gardens, 3500' elev., 22. vii. 1967 , S. Peck and A. Fiske, 6 in 63 lbs. Chestnut stump litter; Craggy Dome, 22.vii.r 960, Barr and Bowling, 9. Haywood County; Richland Balsam, I.viii.ı960, Barr and Bowling, 3. Henderson County; 0.3 mi. S.W. of Bat Cave, Iooo' elev., 22.vii.1967, S. Peck and A. Fiske, 2 in $39 \mathrm{lbs}$. of $\log$ and leaf litter. Madison County; Rich Mt., 3000' elev., 25.vii.r 967 , S. Peck and A. Fiske, 4 in 85 lbs. 


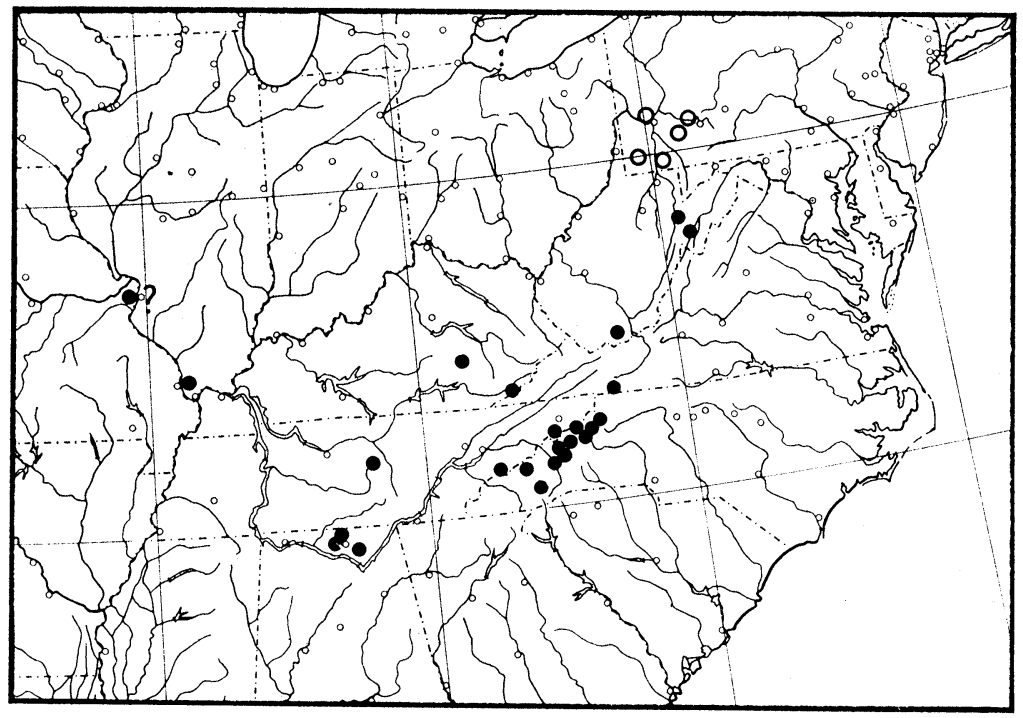

Map 2. East central United States and Catopocerus distributions. Open dots, C. hamiltoni. Closed dots, C. appalachianus.

of rotted stump. Mitchell County; Blue Ridge Parkway, mile 326.8, $3200^{\prime}$ elev., 22.vii.1967, S. Peck and A. Fiske, 2 in 64 lbs. of litter at base of large dead pine tree: Roan Mt., 5000' elev., 25.vii.1967, S. Peck and A. Fiske, 2 in 72 lbs. of litter along rotted beach log. Round Knob, 27.6, Hubbard and Schwarz, I. Yancey County; Hamrick, 3000-3100' elev., 30.xii.I946, Hairston, I in leaf litter: Mt. Mitchell, Balsam Gap, 5300' elev., 9.vi.1967, S. Peck, 9 in birch-beech litter: Mt. Mitchell, 5500' elev., 9.vi.1967, S. Peck, Io in birch-beech litter and I in basal tree hole: Mt. Mitchell, 4000'6000' elev., June 1939, E. D. Quirsfeld, Io: Mt. Mitchell, 26 with no other data: Valley of Black Mts., July 28, 1906, W. Beutenmuller, 3; August 19, 1906, W. Beutenmuller, I. Black Mts., vivii. I902, Van Dyke colln., I4. Tennessee. Coffee County. Beech Grove, Burke Cave, 24.v.73, S. \& J. Peck, I male, I female, at carrion bait. Great Smoky Mt. National Park; Chimneys, 300o' elev., ix.19.1944, A. Nicolay, 2 females. Newfound Gap, 500o5200', August 31, 1930, P. Darlington, I female. Clingmans Dome, 7.vii.1960, T. C. Barr. Unicoi County; Unaka Mtn., 5.vii.1953, H. \& A. Howden, I. Virginia. Grayson County; Whitetop Mtn., 4000' elev. 24.vii.1967, S. Peck and A. Fiske, Io in $77 \mathrm{lbs}$. of $\log$ 
and stump litter; Whitetop Mtn., r3.vii.r96o, T. C. Barr, M. C. Bowling, 4. West Virginia. Mercer County; Athens, 6.vi.r97i, W. Shear, litter, I. Randolf County; 5 mi S. Whitmer, I8.vii. I97I, S. Peck, $3000^{\prime}$, I I in litter. Pendleton County; Spruce Knob, $4000^{\prime}$ elev., 26.viii.r 964, S. Peck \& T. C. Barr, 2 under rocks and 2 in litter. (AMNH, CAS, CNC, FMNH, MCZ, SBP, USNM).

The Illinois collection, separated from the rest of the species' range, is also of special interest because of the unusual nature of the habitat. The collector, Dr. J. M. Campbell, has supplied me with more detailed data on the locality, and I quote from a letter; "Malt trap no. 9 was set in a small stand of Pinus echinata on a very dry site on the S. W. slope near the top of a ridge. There was very little litter on the soil; what little litter there was consisted of pine needles. This entire area of S. Illinois is characterized by having very small stands of pine scattered on the S. W. slopes of dry, rocky ridges. It is possible that any beetles found in this site live in the more mesic ravines which are nearby."

This species may also exist in Missouri. One female labeled "St. Louis, Mo., iv.28" from the Liebeck collection is in the Fall collection in the MCZ. The measurements of the specimen fall into the range of variation of $C$. ulkei, but the Illinois record of $C$. appalachianus suggests that it might more likely occur in Missouri if we accept the accuracy of the specimen label

Life Cycle Data. Eight adult C. appalachianus, captured September I, I968 in Ellis Cave, Madison Co., Alabama, were kept alive in laboratory culture at $15^{\circ} \mathrm{C}$ in plastic dishes of moist soil from Ellis Cave. All adults had died by May i969. Two beetles becoming adults in May I969 died in June and July 1970, suggesting that full adult life may be about one year. Copulation occurred in culture. A total of 37 eggs were laid on the soil surface, with soil crumbs stuck to their sides. The number of females producing these eggs is not known. The month of egg laying and number of eggs were as follows: October, Io; November, 5 ; December, 3 ; January, 2; March, 14; April, 3. Reproduction may thus occur throughout the year, especially under favorable temperature conditions such as in caves or deep rock crevices. The eggs were white and oblong, a sample of six measured $.35-.60 \mathrm{~mm}$ (mean $.48 \mathrm{~mm}$ ) by $.55^{-.75} \mathrm{~mm}$ (mean $.63 \mathrm{~mm}$ ).

A sample of 8 eggs hatched 13 to 20 days (mean I 7 days) after being laid. A sample of 7 larvae had a total life span in this stage of from 26 to 30 days (mean 29 days). The first instar lasted 8 days for I larva. The total number of instars was not determined 
but may be three. Approximately the first 20 days of larval life were spent feeding on the soil surface or in shallow burrows at the edge of the yeast. Approximately the last ten days (6 to I I recorded) of larval life were spent in deepened vertical burrows which were made into pupation chambers. The larvae in these cells became more plump and swollen. Pupation lasted from 16 to 22 days (mean of 20 in a sample of 7). After ecdysis the adults remained in their cells for about a week before emerging. When the adults became reproductively active is not known.

Some of the larvae and pupae were preserved for a study of immature characteristics. They are in the $\mathrm{MCZ}$ beetle larva collections and will be described in a later paper.

\section{Catopocerus jonesi New Species}

Figs. 8, 9; Map I

Holotype male ( $M C Z$ no. 32229) from Eudy Cave, I mi. S. Oleander, Marshall County, Alabama, 23.vi.1942, W. B. Jones leg. Paratypes, in SBP collection: Alabama. Morgan County, Shine Cave (in Newsome Sinks) 7.vii.r957, L. Varnedoe, I female; Vandever Cave, 3 mi. S.S.W. Laceys Spring, 22.v.1972, S. \& J. Peck, I male and I female in rotten sticks at back of cave. Jackson County; House of Happiness Cave, 4 mi. S.W. Scottsboro, 23.v. 1972, S. \& J. Peck, 2 males and I female at carrion bait near entrance.

Diagnosis. The species can be distinguished by the third antennal segment being longer than the second, and the fifth being longer than the fourth and sixth, and by the conspicuous toothed ventral projection of the aedeagus.

Description. Holotype measurements, HW, o.62. PW, I.I2. PL, 0.80, EL, I.56. EW, I.I 7 .

Length 2.54-2.65 mm. Width I.I 5-1.23 mm. Color uniform dark reddish-brown, shining. Shape oblong, sides parallel.

Head with no indications of eyes; clypeus slightly truncate; frons punctate; vertex punctate and finely striolate. Antennae well supplied with long hairs; segments IX, X, XI, possessing dense mat of long and short hairs; segment I robust; II cylindrical, shorter than III by I/4; III conical, as broad as II; IV, VI longer than broad, shorter than V; VII distinctly longer than broad, slightly wider than VIII and longer than VIII by a third; IX slightly narrower than $X$, a third wider than VIII; XI conical at tip.

Pronotum widest at middle; sides evenly arcuate; narrower at front than back; hind angles slightly obtuse; front angles rounded; 
front margin slightly concave; hind margin slightly concave; disc finely punctulate; finely striolate.

Elytra fused; at base slightly wider than base of pronotum; widest near middle; anterior margins subparallel; surface punctate, punctures indicating striae; finely striolate; sides and apex smooth. Protibia straight on outer margin; sinuous on inner margin; widening to apex in apical $2 / 3$; setose on apical half of inner margin; spinose along outer margin; two large spines at outer apical angle; two shorter spines on inner margin at origin of tarsus; comb of short spines below origin of tarsus. Mesotibia straight and spinose along outer margin; curved and setose along inner margin; expanding to apex in apical 2/3; outer apical angle sharp, possessing two spines; one large spine along ventral edge of apical margin. Metatibia stout, gradually widening to apex; outer and inner margin smooth; curved slightly so that apex is deflected outward; straight in lateral view; one large spine at outer apical angle and one in middle of apical margin; dense patch of setae along upper and inner margin of apex. Fifth abdominal segment evenly rounded.

Male first three protarsomeres widely expanded and supplied with a dense mat of hairs; first three mesotarsomeres less expanded and hairy. Aedeagus in lateral view bent near base, basal anterior projection deflected downward, body of aedeagus slightly sinuous and tapering, ventral surface projecting posteriorly to form shelf under genital orifice, dorsal surface curving downward slightly; in ventral view robust, sides parallel, dorsal surface tapering only at apex and smooth in outline, ventral surface with apical tooth-like projection; parameres gradually tapering to point, terminating close to aedeagal apex, basal pieces thin (figs. 8, 9).

Female tarsomeres not expanded.

Variation. No noteworthy variation is evident in the seven known specimens.

Etymology. I am pleased to name this species for Dr. Walter B. Jones, retired State Geologist of Alabama, in recognition of his assistance to me and to other students of Alabama cave fauna.

Distribution. Known only from Morgan, Marshall and Jackson Counties in northeastern Alabama (map I).

Catopocerus alabamae New Species

Figs. IO, II ; Map I

Known only from Holotype male (MCZ no. 32230) from Cave Spring Cave, Chapman Mtn., I mi. N.E. Huntsville, Madison Co., 
Alabama, found in the stomach of a plethodontid salamander Eurycea lucifuga, captured 8.ix.1965, S. Peck leg.

Diagnosis. Most similar to $C$. jonesi but differing from it and all other species in the shape of the aedeagus, the very widely expanded male tarsal segments, and the distinct setal bearing excavation on the inner and upper margin of the hind tibia.

Description. Measurements of the Holotype. HW, .70. PW, I.25. EL, I.78. EW, I.30. Color uniform dark reddish brown, shining. Shape rectangular, rounded at front and back.

Head with no traces of eyes; vertex finely punctulate; frons coarsely punctate. Antennae with hairs on all segments; segments IX, X, XI also supplied with dense cover of short hairs at their apical margins; segment I stout; II shorter than III, III slightly conical; IV, VI larger than broad, shorter than V; VII larger than wide, larger than VIII, smaller than IX; IX longer than wide; $X$ as long as wide; XI conical at tip.

Pronotum widest at middle; sides evenly arcuate; narrower at front than back; hind angles slightly obtuse; front angles rounded; front margin slightly concave; hind margin slightly concave; disc finely puntulate, coarsely set with punctures.

Elytra fused; at base slightly wider than base of pronotum; widest near middle; surface finely punctulate, with larger punctures indicating 5 distinct and a sixth indistinct stria. Protibia widened at apex, protarsi conspicuously expanded and setose. Mesotibia widened at apex, mesotarsi conspicuously expanded and setose. Metatibia with setae bearing excavation in posterior third of dorsal and inner surface. Metatarsi not expanded. Fifth abdominal segment evenly rounded.

Aedeagus in lateral view (fig. Io) wide, without ventral projection, expanded in posterior half. In ventral view (fig. I I) wide and slightly expanded toward posterior. Parameres gradually tapering, terminating close to aedeagal apex, basal pieces thin.

Notes on holotype. The tip and left side of the aedeagus were damaged in dissection. The illustrations are reconstructed except for the dorsal tip whose full size and shape are not known.

Etymology. The name refers to the state of Alabama.

Distribution and habitat notes. The species is probably a deep soil inhabitant, limited to northeastern Alabama. 'The type locality is a small cave under the sandstone cap of Chapman Mountain. A seep spring in the cave gives the cave its name. I have visited the cave many times since 1965 in unsuccessful attempts at obtaining more specimens by searching by hand under rocks and litter and by 
using bait. The salamander which obtained the beetle as food undoubtedly did so from a small and/or inaccessible population in or near the cave. Catopocerus are not commonly eaten by terrestrial cave salamanders. I have examined the digestive tract contents of 433 salamanders from caves within the range of Catopocerus in the southeastern U. S. (Peck, I974: Richardson and Peck, in MS) and no other Catopocerus have been found.

\section{Evolution and Distribution}

We may assume that the genus had a past transcontinental range. The present division of the generic range into the ecologically isolated eastern and western forested regions may date from the Miocene when drying conditions caused a retreat of the Neotropical flora from western North America. This range division was probably widened with the later Pliocene arid trend associated with the northward invasion of the Madro-Tertiary geoflora which gave rise to the recent xerophytic vegetation (Axelrod, 1958).

Since this division, there is little that can be said of speciation and distributional events for the eastern species. A more rich history is evident in the western species, but will be discussed in a later paper. The three eastern species with limited distributions $(C$. hamiltoni, $C$. alabamae, and $C$. jonesi) probably experienced a contraction to their present ranges, from a wider ancient range, in connection with Pleistocene climatic events. None of these species is closely related to the other.

C. applachianus and C. ulkei, however are similar enough to have been derived from a single common ancestral species which may have inhabited the Appalachians from at least Pennsylvania to North Carolina. A division of the range into two main units during an early interglacial may have allowed $C$. ulkei to diverge in the north from Virginia perhaps to Pennsylvania, and allowed $C$. appalachianus to diverge in the south in North Carolina. C. ulkei may have then dispersed southward during the Illinoisan glaciation to southwestern North Carolina. These populations may have become isolated and somewhat divergent during the Sangamon interglacial. Other overlap of the ranges of the two species may have occurred by dispersal in the Illinoisan, as well as the Wisconsinan. However, judging from the lack of other geographic variation, most of the present distributions were probably gained in the $W$ isconsinan. This was the time when the larger and perhaps more vagile $C$. appalachianus moved north into Virginia and West Virginia. The populations of this species in 
the Cumberland Plateau of Kentucky and Alabama, the Highland Rim of Tennessee, and the Shawnee Hills of southern Illinois are probably not remnants of an ancient distribution but also date from the Wisconsinan glaciation when more wet and cool montane-type climatic conditions prevailed in the Interior Basins, favoring the distribution and dispersal of "montane" beetles.

The comparatively large ranges and low levels of geographic variability in C. ulkei and C. appalachianus are remarkable in the light of an assumed low dispersal potential resulting from the beetles' winglessness, eyelessness, and soil habitation. Other ecologically similar beetles, for instance Anillinus and Arianops (Barr, 1969; 1974) in the eastern United States have much smaller ranges and are more highly speciated. In contrast then, it must be that the vagility of some Catopocerus is higher than would seem likely at first, because of an incompletely understood ability to withstand various mechanisms of long distance dispersal, similar to that of some European soil Colydiid beetles (Peck, I972).

\section{Acknowledgements}

I thank the following persons and their institutions for allowing examination of specimens: M. G. Emsley, ANSP; L. H. Herman, AMNH; H. B. Leech, CAS; J. M. Campbell, CNCI; H. Dybas and R. Wenzel, FMNH; M. W. Sanderson, INHS ; P. J. Darlington and J. F. Lawrence, MCZ; J. M. Kingsolver, USNM; Fr. Jerome Rupprecht, SVAM; G. E. Wallace, CM; and G. Byers, UK. Thomas C. Barr, University of Kentucky, and Henry F. Howden have provided specimens from their personal collections. Collections made in regions administered by the National Park Service were permitted by Ernest G. Whanger, Blue Ridge Parkway, and V. R. Bender, Great Smoky Mountains National Park. A debt of gratitude is due to many persons who assisted me in collecting, especially James H. Peck in 1965, Alan Fiske in 1967, and Jarmila Kukalova-Peck. Dr. and Mrs. Walter B. Jones of Huntsville, Alabama, are thanked for their hospitality in providing a base for field work conducted intermittently in and near Alabama over seven years. My wife, Jarmila, prepared the final illustrations. My specimens were collected during field work supported by National Science Foundation Grants GB 3167 and GB 7346 (Professor Reed C. Rollins, principal investigator, Biological Laboratories, Harvard University) and by Canadian National Research Council operating grants. John Lawrence and Ernst Mayr kindly read an early version of the manuscript. 


\section{Literature Cited}

AXELROD, D.

1958. Evolution of the Madro-Tertiary gloflora. Bot. Rev., 24: 433509.

BARr. T. C., JR.

1969. Evolution of the (Coleoptera) Carabidae in the southern Appalachians, 67-92 in P. Holt ed., The distributional history of the biota of the southern Appalachians, part I: Invertebrates. Research Div. Mono. 1, Virginia Polytech. Inst., Blacksburg, Va. $295 \mathrm{pp}$.

19\%4. The eyeless beetles of the genus Arianops Brendel (Coleoptera, Pselaphidae). Amer. Mus. Nat. Hist. Bull. 154(1): 1-51.

BROWN, W. J.

1933. Two undescribed species of the old family Silphidae with notes on some characters that have been used to divide the group. Can. Ent., 65: 213-215.

Hamilton, J.

1894. Catalogue of the Coleoptera of Alaska with the synonymy and distribution. Trans. Amer. Ent. Soc., 21: 1-38.

1897. Pinodytes hamiltoni and Anthicus formicarius. Ent. News, 8: 34-35.

НАТсH, M. H.

1957. The beetles of the Pacific Northwest; part II: Staphyliniformia. University of Washington Press, Publications in Biology, vol. 16, Seattle, $384 \mathrm{pp}$.

HORN, G. H.

1880. Synopsis of the Silphidae of the United States with reference to the genera of other countries. Trans. Amer. Ent. Soc., 8: 219-322.

1892. Random studies in North American Coleoptera. Trans. Amer. Ent. Soc., 14: 40-47.

PECK, S. B.

1972. The eyeless European soil Colydiid, Anommatus duodecimstriatus, in North America (Coleoptera; Colydiidae). Coleop. Bull., 26: 19-20.

1973. A systematic revision and the evolutionary biology of the Ptomaphagus (Adelops) beetles of North America (Coleoptera, Leiodidae; Catopinae), with emphasis on cave-inhabiting species. Bull. Mus. Comp. Zool., 145(2) : 29-162.

1974. The food of the salamanders Eurycea lucifuga and Plethodon glutinosus in caves. Nat. Speleol. Soc. Bull., 36(4):1-10.

Valentine, J. M.

1942. On the preparation and preservation of insects, with particular reference to Coleoptera. Smithsonian Misc. Coll., $103(6)$ : 1-16. 

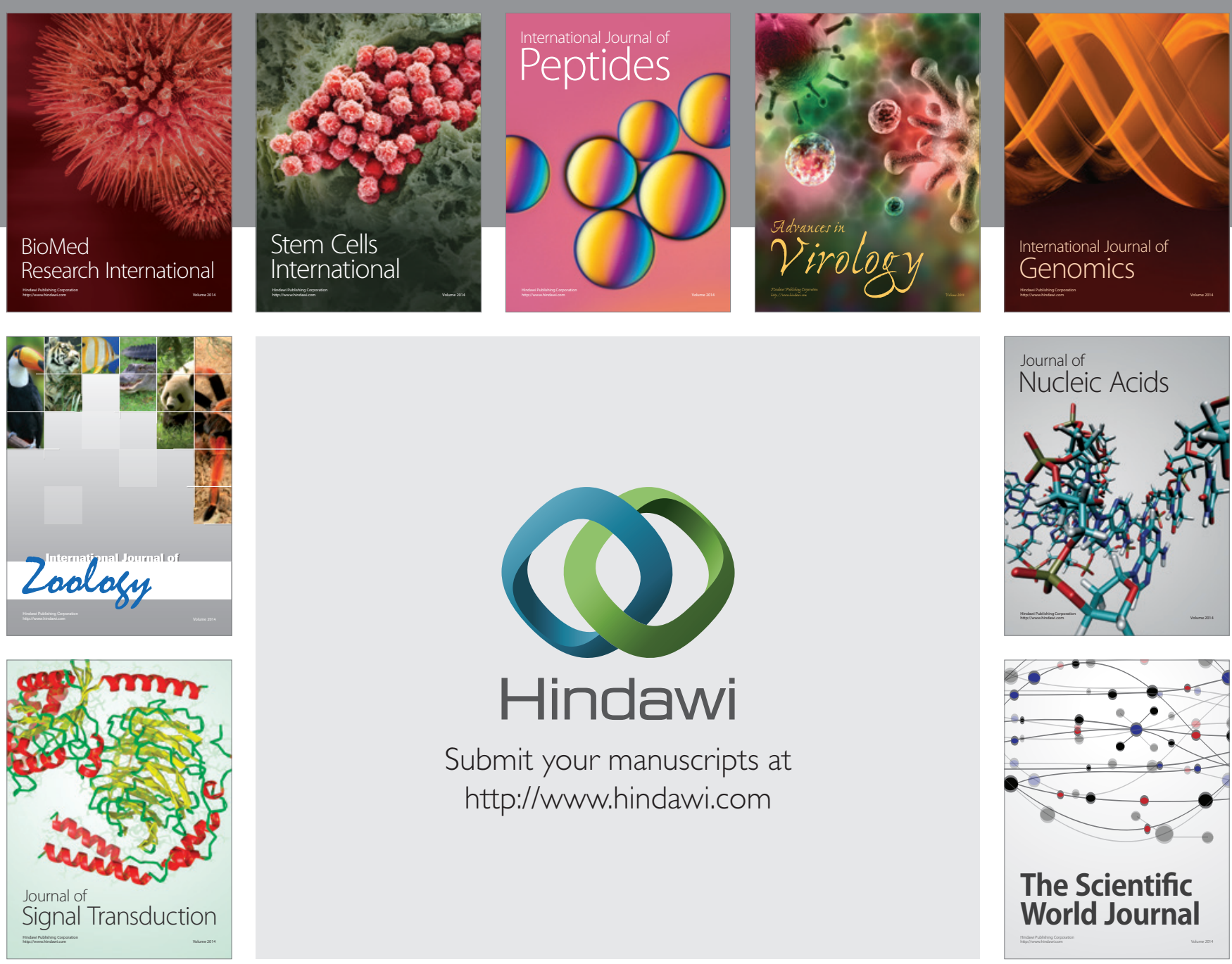

Submit your manuscripts at

http://www.hindawi.com
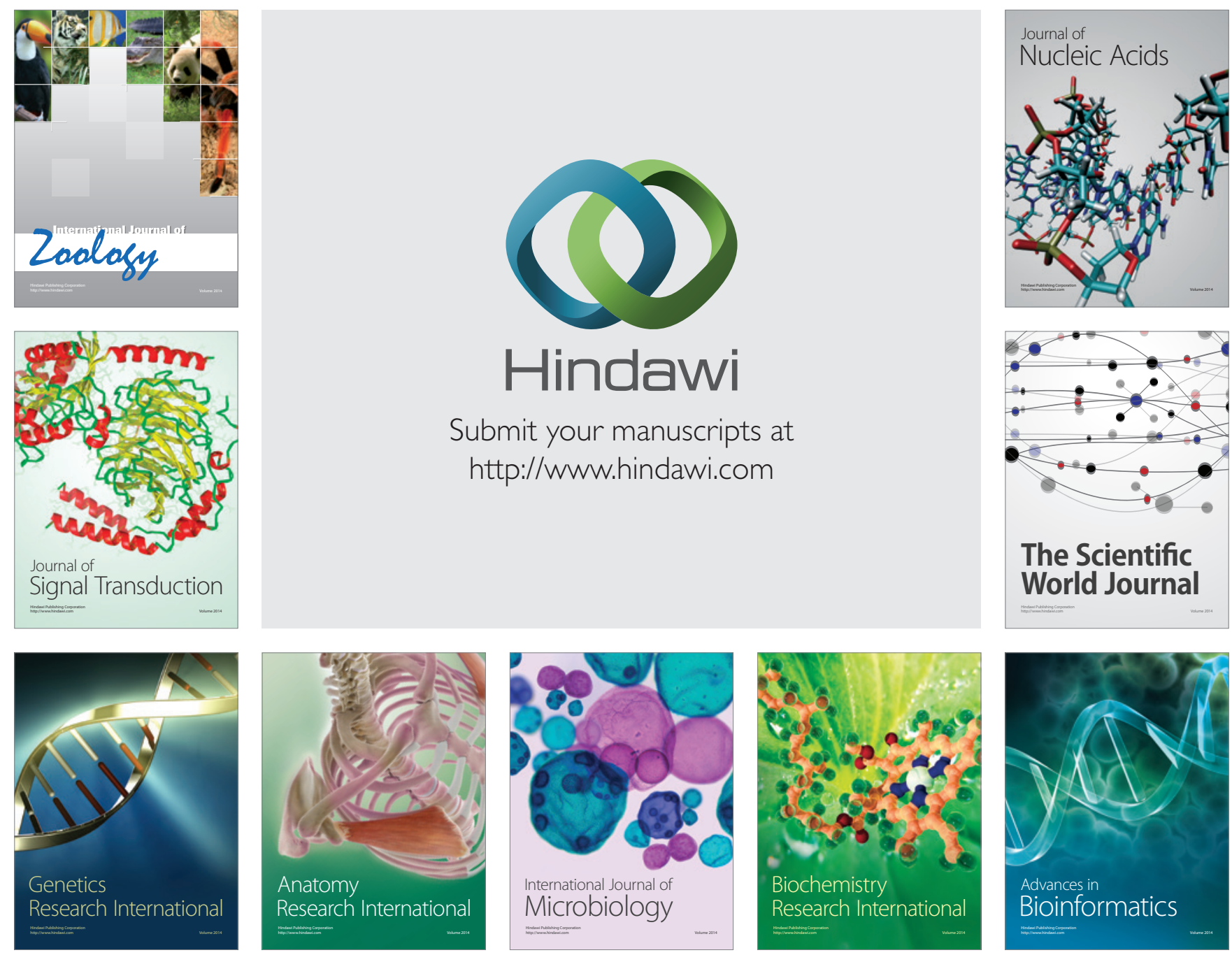

The Scientific World Journal
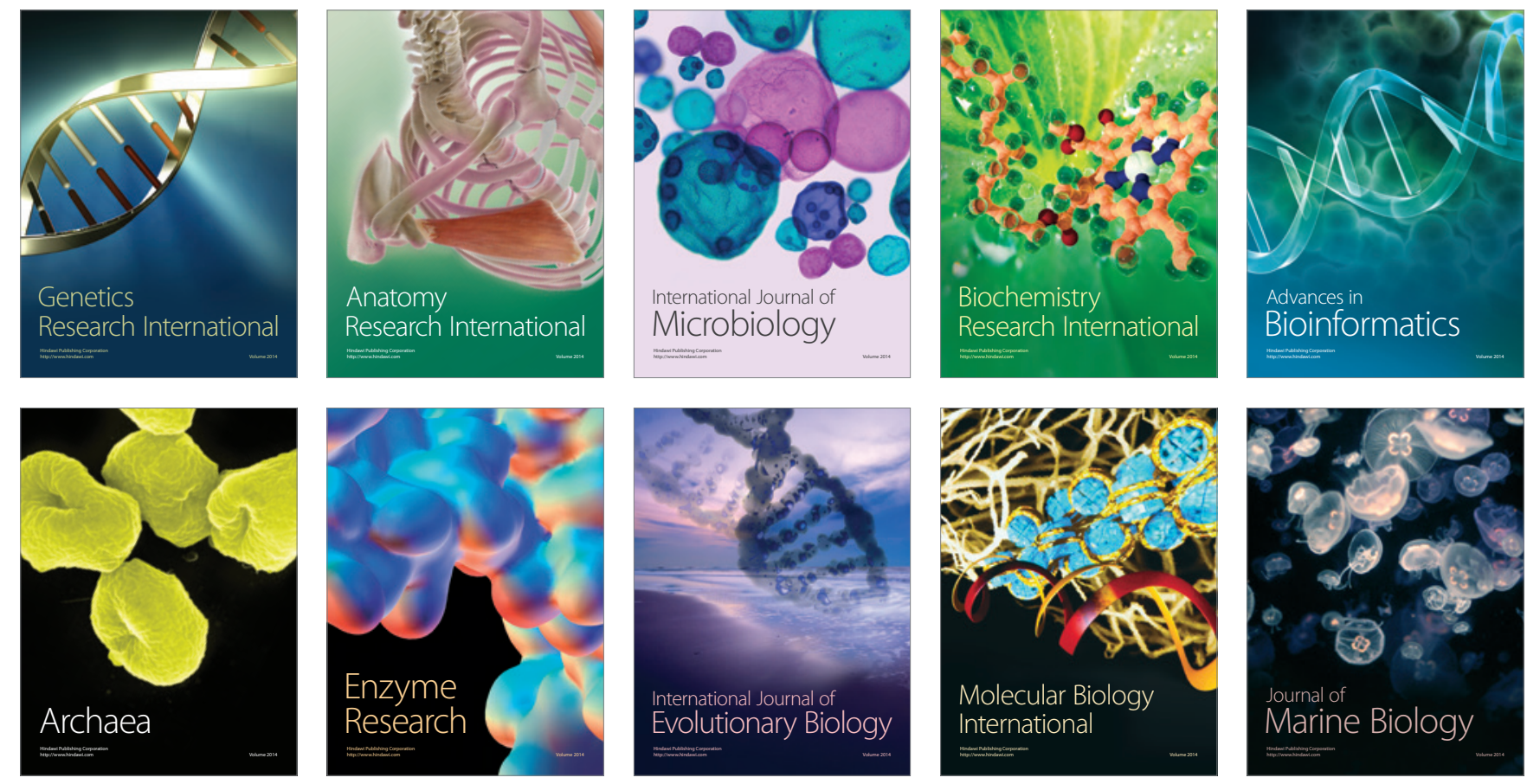